NBER WORKING PAPER SERIES

\title{
DEBT REDEMPTION AND RESERVE ACCUMULATION
}

\author{
Laura Alfaro \\ Fabio Kanczuk \\ Working Paper 19098 \\ http://www.nber.org/papers/w19098 \\ NATIONAL BUREAU OF ECONOMIC RESEARCH \\ 1050 Massachusetts Avenue \\ Cambridge, MA 02138 \\ June 2013, Revised June 2018
}

The paper does not reflect the views of the Brazilian Ministry of Finance or the National Bureau of Economic Research. We thank for their valuable comments and suggestions Emine Boz, Nan Li, two anonymous referees, Enrique Alberola-Ila, Javier Bianchi, Roberto Chang, Menzie Chinn, Charles Engel, Jeffrey Frankel, Marcio Garcia, Galina Hale, Ricardo Hausmann, Lakshmi Iyer, Carmen Reinhart, Jesse Schreger, Eric Werker, and participants in seminars at the Kennedy School of Government, Harvard Business School, Fundacão Getulio Vargas, University of São Paulo, University of Wisconsin-Madison, and participants at the LACEA, and the Brazilian Central Bank Inflation Targeting Conference. Hayley Pallan and Haviland Sheldahl-Thomason provided great research assistance. Support from Harvard Business School research budget acknowledged.

NBER working papers are circulated for discussion and comment purposes. They have not been peer-reviewed or been subject to the review by the NBER Board of Directors that accompanies official NBER publications.

(C) 2013 by Laura Alfaro and Fabio Kanczuk. All rights reserved. Short sections of text, not to exceed two paragraphs, may be quoted without explicit permission provided that full credit, including (C) notice, is given to the source. 
Debt Redemption and Reserve Accumulation

Laura Alfaro and Fabio Kanczuk

NBER Working Paper No. 19098

June 2013, Revised June 2018

JEL No. F31,F34

\begin{abstract}
$\underline{\text { ABSTRACT }}$
In the past decade, foreign participation in local-currency bond markets in emerging countries has increased dramatically. We revisit sovereign debt sustainability under the assumptions that countries can borrow internationally using their own currencies and accumulate reserves. As opposed to traditional sovereign-debt models, asset-valuation effects occasioned by currency fluctuations act to absorb global shocks and smooth consumption. Countries do not accumulate reserves to be depleted in "bad" times. Instead, issuing domestic debt while accumulating reserves acts as a hedge against external shocks. A quantitative exercise of the Brazilian economy suggests this strategy to be effective for smoothing consumption and reducing the occurrence of default.
\end{abstract}

Laura Alfaro

Harvard Business School

Morgan Hall 263

Soldiers Field

Boston, MA 02163

and NBER

lalfaro@hbs.edu

Fabio Kanczuk

University of São Paulo

R. Dr Alberto Cardoso de Melo Neto 110/131A

Sao Paulo-S.P.-CEP 01455-100

BRAZIL

kanczuk@usp.br 


\section{Introduction}

The past decade witnessed the impressive development of domestic government bond markets in emerging market economies (EMEs). Market depth increased, maturities lengthened, and the investor base broadened as a consequence of active foreign participation in local currency bond markets. At the same time, EMEs accumulated international reserves. However, since the interest earned from international reserves is much lower than that paid on EMEs' debts, this policy seems puzzling. What is the role of international reserves if these countries have the option of inflating away domestic debt facing no significant external liquidity risks? Why are these reserves not used to repay debt? Are international reserves ultimately increasing or decreasing the sustainability of EMEs' debts?

This paper revisits the question of the optimal level of debt and foreign reserves under novel assumptions that reflect the recent developments of capital flows to emerging markets. In particular, increased foreign participation in local-currency bond markets implies that emerging countries borrow internationally in domestic-currency-denominated bonds. This makes them subject to new sets of constraints regarding repayment of their liabilities, and exposes them to new incentives to actively accumulate international reserves.

We modify a standard model of sovereign debt to quantitatively study how countries should react to this new reality. We obtain that optimal reserve holdings turn out to be as large as those observed in the data, and that default almost never occurs. This approach differs from the traditional model, in that asset valuation effects contribute most significantly to consumption smoothing. Our results suggest that joint issuance of domestic-denominated debt and international reserves act as a powerful hedge against external shocks.

These results are congruous with two trends that have characterized capital flows and portfolio holdings of emerging countries over the past decade. The first is a strong increase in 
foreign participation in local-currency bond markets in emerging economies. Using a newly constructed dataset of the currency composition of sovereign and corporate external debt, $\mathrm{Du}$ and Schreger $(2015 \mathrm{a}, \mathrm{b})$ show that over the past decade, major emerging market sovereigns that borrowed as much as $85 \%$ of their external debt in foreign currency now borrow more than half in their own currencies (see also Burger et al. (2012)). Figure 1 displays the increase in domestic-currency-denominated debt in a sample of emerging markets.

Figure 1: Domestically-Denominated Debt as a Fraction of Total Government Debt (\%)

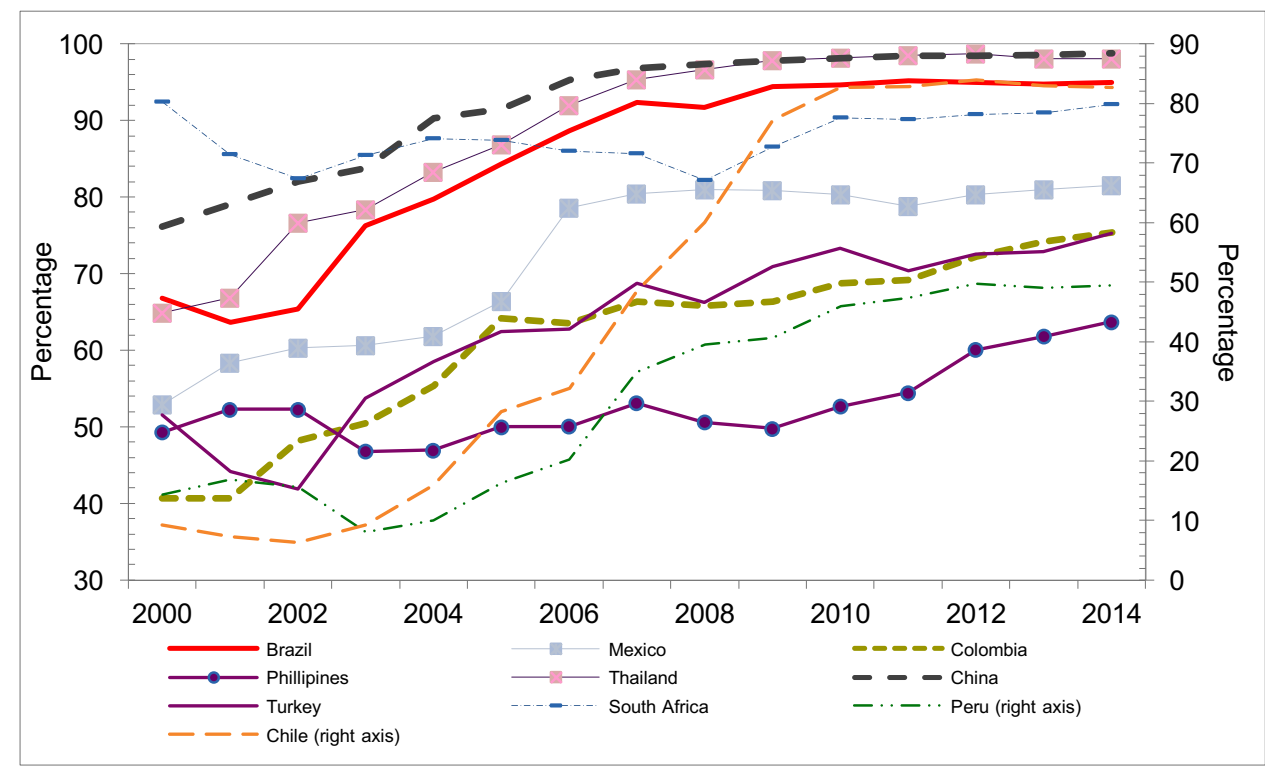

Source: Moody’s Statistical Handbook, 2014.

The second trend is the accumulation of international reserves, depicted in Figure 2. The average level of reserves in 2014 was more than $25 \%$ of GDP in emerging countries, and only approximately 5\% of GDP in high-income countries. As documented by the European Central Bank (2006), the size and pace of accumulation of foreign reserves has been unprecedented. Countries have accumulated reserves greater than their IMF quotas, exhibiting ratios of reserves to imports above four months of coverage, reserves to short-term external debt maturities above one year (Greenspan-Guidotti rule) and broad money. The increase in reserve assets is not limited to China or the East Asian countries; its ubiquity 
among developing countries has raised interesting questions in academic and policy circles about the costs and benefits of reserve accumulation.

The cost of holding reserves has been estimated at approximately 1\% of GDP for all developing countries (Rodrik, 2006). Against this cost, the commonly advanced explanation is that reserves are accumulated as insurance against the risk of an external crisis, by providing increased liquidity. However, borrowing constraints for emerging countries are quite different from what they used to be. More than fifteen years ago, Eichengreen and Hausmann (1999) advanced the original-sin hypothesis on the limits of emerging markets' ability to borrow in their own currency. But the gradual redemption of these economies' debt sins over the past decade might naturally be expected to significantly affect incentives related to debt default and repayment.

Figure 2: International Reserves (\% GDP)

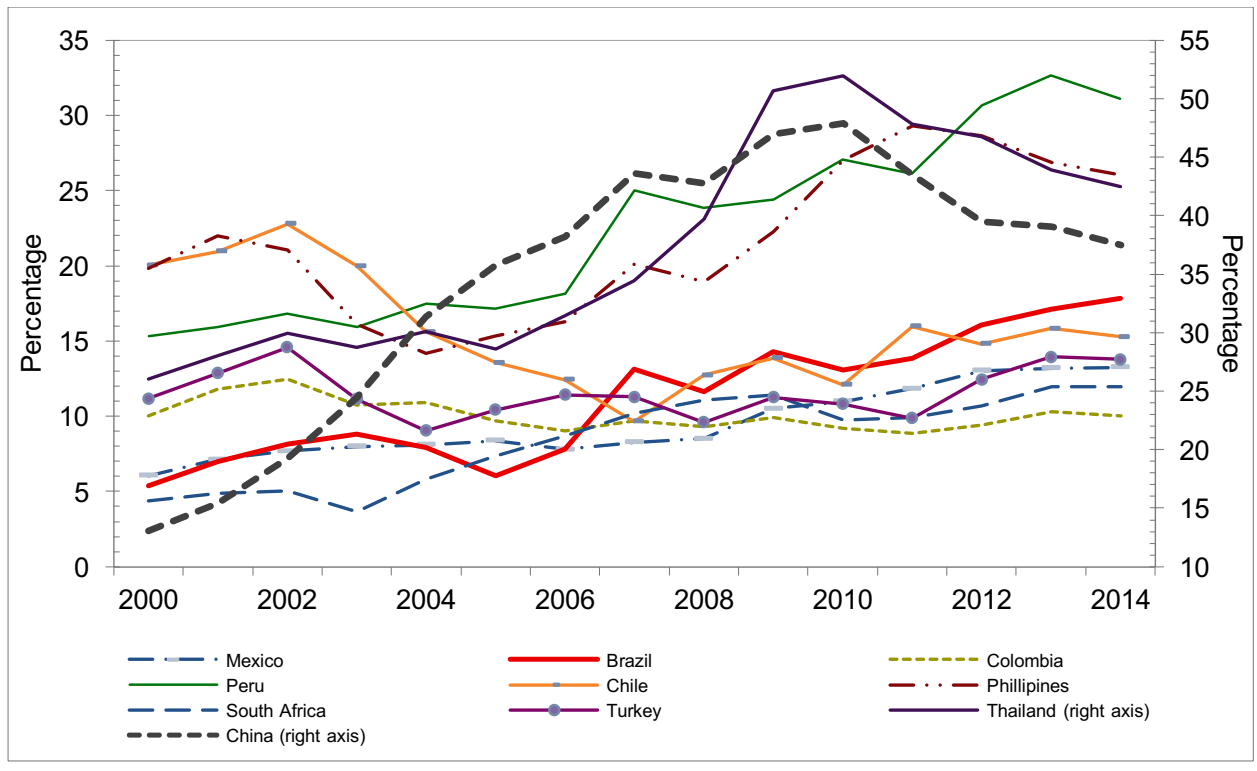

Source: Moody’s Statistical Handbook, 2014.

In this paper, we study the joint determination of domestic-currency debt and foreign reserve accumulation by constructing a dynamic equilibrium model of a small open economy subject to international shocks. To smooth consumption, a benevolent government may issue 
foreign debt in domestic and international currencies denominated in the price of nontradable and tradable goods, respectively. Domestic and international interest rates may differ, and we explicitly model the risks associated with such differences. We calibrate our model to Brazil, a typical example of an emerging country that accumulated international reserves during debt redemption.

The basic intuition for our model goes back at least to Bohn (1990), but its empirical implementation has only recently begun to be studied (see Benetrix, Lane, and Shambaugh, 2015). Having positive net foreign currency positions (assets in foreign currency and debt in domestic currency) is optimal when a country faces international shocks (such as the endowment of tradable goods). This is because the asset valuation effects occasioned by currency depreciation (or appreciation) act to absorb global shocks and smooth consumption.

Debt and reserve accumulation also affect, and are affected by, a country's incentives to default. A large stock of domestically denominated debt could help counterbalance an external shock but may not be sustainable. A country might not resist the temptation to default on such a large debt, and could default through such methods as surprise inflation and an outright restructuring of its services. Very large holdings of international reserves may also not be optimal. International reserves that are unable to be pledged may not increase the sustainability of debt. In fact, these reserves may reduce sustainability when debt is denominated in foreign currency (Alfaro and Kanczuk, 2009). Additionally, because holdings of international reserves shift consumption to later dates, they may be excessively costly.

Our quantitative results suggest that the optimal level of international reserves is fairly large, as the cost of holding these reserves is mitigated by valuation-smoothing gains. Our model also matches some features of Brazil's economic fluctuations, being consistent, in particular, with the reduction in exchange rate volatility. 
In our analysis, issuing domestic debt while accumulating high levels of reserves acts as a hedge against negative external shocks. That is, differently from previous work, countries do not accumulate high levels of reserves to be depleted in "bad" times, as is usually suggested in policy circles. This result relates to the vast literature on valuation effects and optimal international portfolio diversification (Cole and Obstfeld (1991), Engel and Matsumoto (2009), Alfaro and Kanczuk (2010), Healthcote and Perri (2013), and Gourinchas and Rey (2014)). We contribute to this literature by explicitly considering a sovereign's incentive to default, thus incorporating sustainability of portfolio choices in our analysis. In further contrast to previous literature, asset yields and exchange rates are endogenously determined in the model, and are dependent on the government's portfolio choice.

Our paper also relates to the growing literature that examines debt sustainability (see Aguiar and Amador (2014) and Aguiar et al. (2016) for recent surveys of the literature), particularly to analyses of the recently increasing role of local-currency debt in emerging markets (Burger et al. (2012), Du and Schreger (2015 a, b), Hale et al. (2014), Ottonello and Perez (2017)). Our paper adds to this literature by examining the determinants of reserve accumulation in emerging markets. The rationale for reserve accumulation based on interaction with local currency external debt (i.e., "redemption" of the "original sin"), which was also put forth by Jeanne and Rancière (2011), complements explanations that emphasize precautionary motives and roll-over risk (Alfaro and Kanczuk (2009), Durdu, Mendoza, and Terrones (2009) and Bianchi et al. (2012)), financial stability (Obstfeld, Shambaugh, and Taylor (2010)), externalities associated with the tradable sector or mercantilist view (Dooley, Folkerts-Landau, and Garber (2003), and Benigno and Fornaro (2011)) and political economy considerations (Aizenman and Marion (2003)). 
The rest of the paper is organized as follows. In Section 2, we derive intuition from a two-period, stripped down version of the model. In Section 3, we present the infinite-period general model. In Section 4, we calibrate the model to Brazil's economy and discuss the results of the quantitative simulation. In Section 5, we present further analyses of the main results, discuss the robustness of the exercises. Section 6 concludes this study.

\section{Two-Period Version of the Model}

We first develop a two-period, stripped-down version of the model to provide intuition for the joint determination of international reserves and domestically-denominated debt. Although the model cannot shed light on the sovereign's "willingness to pay" incentives, which hinge on the costs from defaulting, this simpler version underscores how the combination of reserves and debt provides insurance against international shocks and allows for intratemporal consumption smoothing.

In this simple economy, the sovereign consumes only in the second period. In the first period, she decides her holdings of debt and reserves for the second period, which are denoted respectively by $D$ and $R$. The sovereign's preferences are given by:

$$
u\left(c^{N}, c^{T}\right)=E\left[\log \left(c^{N}\right)+\log \left(c^{T}\right)\right],
$$

where households' second period consumption of non-tradable and tradable goods are respectively denoted by $c^{N}$ and $c^{T}$, and $E$ represents expectation. In the first period, households do not have any endowment, which implies that $D=R$ (the first period exchange rate was normalized to one). In the second period, households receive an endowment of a unit of consumption of non-tradable good, $y^{N}=1$, and their endowment of the tradable good follows a stochastic process:

$$
\begin{aligned}
& y_{\mathrm{G}}^{T}=(1+\sigma), \text { with probability equal to } 1 / 2(\text { good state of nature }), \text { and } \\
& y^{T}{ }_{\mathrm{B}}=(1-\sigma), \text { with probability equal to } 1 / 2(\text { bad state of nature }) .
\end{aligned}
$$


Reserves correspond to riskless bonds that bear interest rates given by $\rho$. Debt can be issued either in foreign currency or domestic currency. We assume the sovereign repays debt in both the good and bad states of nature. In other words, default cannot be used to smooth consumption.

\subsection{Domestic Denominated Debt}

When debt is issued in domestic currency, households' budget constraints can be written as:

$$
\begin{gathered}
c_{G}^{T}+\frac{c_{G}^{N}}{e_{G}}=(1+\sigma)+\frac{1}{e_{G}}+R(1+\rho)-\frac{D(1+r)}{e_{G}} \text { in the good state of nature, and } \\
c_{B}^{T}+\frac{c_{B}^{N}}{e_{B}}=(1-\sigma)+\frac{1}{e_{B}}+R(1+\rho)-\frac{D(1+r)}{e_{B}} \text { in the bad state of nature, }
\end{gathered}
$$

where $r$ denotes the interest rate on domestically-denominated debt. International investors are risk neutral, and must be indifferent between international assets and domestic bonds. This implies:

$$
(1+\rho)=\frac{(1+r)}{2}\left[\frac{1}{e_{G}}+\frac{1}{e_{B}}\right] .
$$

In each state of nature, households' optimizations determine the real exchange rate according to the relative marginal utility of tradable and non-tradable goods. Logarithmic utilities imply the exchange rates are given by $e_{G}=1 / c^{T}{ }_{G}$ and $e_{B}=1 / c^{T}{ }_{B}$. Market clearing forces the consumption of non-tradables to equal the endowment of non-tradables. By plugging the exchange rate into the budget constraints, the government problem can be written as maximizing:

$$
u\left(c_{G}^{T}, c_{B}^{N}\right)=\log \left(c_{G}^{T}\right)+\log \left(c_{B}^{T}\right),
$$


subject to:

$$
\begin{gathered}
R=D, \\
c_{G}^{T}=1+\sigma+R(1+\rho)-D c_{G}^{T}(1+r), \\
c_{B}^{T}=1-\sigma+R(1+\rho)-D c_{B}^{T}(1+r), \\
(1+r)\left(c_{G}^{T}+c_{B}^{T}\right)=2(1+\rho) .
\end{gathered}
$$

Before considering that $D=R$, suppose that $c^{T}{ }_{G}+c^{T}{ }_{B}$ equals approximately two, such that the last constraint can be approximately written as $r=\rho$. In this case, it becomes straightforward to plug the constraints into the maximization as follows:

$$
u=\log \left(\frac{1+\sigma+R(1+\rho)}{1+D(1+\rho)}\right)+\log \left(\frac{1-\sigma+R(1+\rho)}{1+D(1+\rho)}\right)
$$

To make consumption the same in the good and bad states, the government could set either a very high $D$ or very high $R$, or both. Since $D=R$, the solution is to make them both very high. (Note that, as a consequence, $c^{T}{ }_{G}+c^{T}{ }_{B}$ equals two, and $r=\rho$ ).

The result here is that domestic-denominated debt is a very effective insurance device. Large holdings of domestic debt (in conjunction with large amounts of reserves) make consumption approximately equal across different states of nature.

To better grasp the mechanics of how this is accomplished, consider again the household budget constraint after plugging in the market clearing condition for non-tradable goods. They imply that the consumption of tradable goods are:

$$
\begin{aligned}
& c_{G}^{T}=(1+\sigma)+R(1+\rho)-\frac{D(1+r)}{e_{G}} \quad \text { in the good state of nature, and } \\
& c_{B}^{T}=(1-\sigma)+R(1+\rho)-\frac{D(1+r)}{e_{B}} \quad \text { in the bad state of nature. }
\end{aligned}
$$

There are two terms that make consumption different depending on the state of nature. One term is the endowment shock, i.e., the sign of sigma. The other term is the domestic denominated debt, which is valued by different exchange rates. 
If the exchange rate appreciates in good states of nature, then the second term offsets the effect of the first term. It turns out that this is exactly the case. Market clearing conditions imply that the exchange rate appreciates in a good state of nature and depreciates in a bad state of nature, thus generating valuation effects over domestic-denominated debt. These valuation effects work as an insurance device by paying out more in worse states of nature.

\subsection{Foreign-Denominated Debt}

If debt is issued in foreign currency, the household's budget constraint would be written as:

$$
\begin{gathered}
c_{G}^{T}+\frac{c_{G}^{N}}{e_{G}}=(1+\sigma)+\frac{1}{e_{G}}+R(1+\rho)-D(1+r) \text { in the good state of nature, and } \\
c_{B}^{T}+\frac{c_{B}^{N}}{e_{B}}=(1+\sigma)+\frac{1}{e_{B}}+R(1+\rho)-D(1+r) \text { in the bad state of nature, and }
\end{gathered}
$$

since there is no default, $\rho=r$.

As before, to derive some intuition and before considering that $D=R$, we plug in the exchange rates obtained by the market clearing condition to obtain the government problem

$$
u=\log (1+\sigma+(R-D)(1+\rho))+\log (1-\sigma+(R-D)(1+\rho))
$$

To make consumption the same in both states, the government would have to make $(R$ - D) very large. Of course this is not possible, as $D=R$. This happens because the government lacks an instrument to redistribute resources across states of nature, and can only redistribute resources across different time periods.

The conclusion of this section is that domestic-denominated debt provides the government with a natural way of insuring against income shocks to the tradable good. Large amounts of domestic debt (in conjunction with large holdings of international reserves) imply that the valuation effects become very effective as a smoothing device. In other words, small 
endowment shocks are translated into large offsetting payoffs. In turn, this allows for consumption smoothing across different states of nature.

In contrast, the role of foreign-denominated debt is to transfer resources across time. As such, it does not provide any intratemporal insurance. In this simple model, where consumption happens in only one period, foreign-denominated debt plays no role in consumption smoothing.

Note that because this two-period model abstracts from default incentives, it cannot shed light on the amount of debt and reserves a sovereign chooses to accumulate. Indeed, the optimal solution in this simple case is for the government to hold infinite amounts of debt and reserves. However, if we consider the possibility of default, there could be limits to the amounts of debt the government would hold before resorting to default. In other words, default considerations imply the need to analyze debt sustainability. And debt sustainability considerations could, in turn, affect how much consumption smoothing could be provided by the issuance of domestic debt. The next section tackles these issues.

\section{General Model}

We model an economy populated by a continuum of private households, a benevolent government, and a continuum of international, risk-neutral investors. Preferences are concave, implying that households prefer a smooth consumption profile for both tradable and non-tradable goods. To smooth consumption, a benevolent government may optimally issue foreign debt in domestically-denominated currency and accumulate foreign reserves. The benevolent government may further optimally choose to default on its international commitments, in which case we assume it to be temporarily excluded from borrowing in 
international markets. Default can be thought of as surprise inflation or as an outright default. $^{1}$

We assume the households' preferences to be given by:

$$
U=E \sum_{t=0}^{\infty} \beta^{t} u\left(c_{t}^{T}, c_{t}^{N}\right)
$$

with:

$$
u\left(c^{T}, c^{N}\right)=\frac{\left[\omega\left(c^{T}\right)^{-\eta}+(1-\omega)\left(c^{N}\right)^{-\eta}\right]^{\left(\frac{1-\sigma}{-\eta}\right)}-1}{(1-\sigma)},
$$

where $E$ is the expectation operator, $c^{T}{ }_{t}$ and $c^{N}{ }_{t}$ denote, respectively, household consumption of tradable and non-tradable goods, $\sigma>0$ measures the curvature of the utility, $\eta$ measures the degree of substitution between tradable and non-tradable goods, $\omega$ indicates the relative importance of these goods to household preferences, and $\beta \in(0,1)$ represents the discount factor.

If the government chooses to repay its debt, the country's budget constraint is given by:

$$
c_{t}^{T}+\frac{c_{t}^{N}}{e_{t}}+q_{t}^{R} R_{t+1}-q_{t}^{D} \frac{D_{t+1}}{e_{t}}=y_{t}^{T}+\frac{y_{t}^{N}}{e_{t}}+R_{t}-\frac{D_{t}}{e_{t}},
$$

where $R_{t}$ denotes the foreign reserves level, $D_{t}$ denotes the domestic denominated debt level, and $y^{T}{ }_{t}$ and $y^{N}{ }_{t}$ are, the tradable and non-tradable goods endowments of output, respectively. The debt and reserve price schedules, $q^{R}\left(s_{t}, R_{t+1}, D_{t+1}\right)$ and $q^{D}\left(s_{t}, R_{t+1}, D_{t+1}\right)$, and real exchange rate function, $e\left(s_{t}, R_{t+1}, D_{t+1}\right)$, are endogenously determined in the model, and are dependent on the state of the economy, $s_{t}$, as well as on the government's decisions. In the benchmark

\footnotetext{
${ }^{1}$ Reinhart and Rogoff (2009) document the main stylized facts regarding sovereign debt and default. As the authors document, the cases of full outright default, as are those of outright repudiation of domestic debt, are rare. Historical average haircut of outright default was around 30\%. In other words, the assumption of full default is a useful simplification both in the case of inflation and outright default.
} 
version of the model, the state of the economy is completely defined by the ordered set $s_{t}=$ $\left(R_{t}, D_{t}, y^{T}{ }_{t}, y_{t}^{N}\right)$.

When the government defaults, the economy's constraint is:

$$
c_{t}^{T}+\frac{c_{t}^{N}}{e_{t}}+q_{t}^{R} R_{t+1}=y_{t}^{D}+\frac{y_{t}^{N}}{e_{t}}+R_{t},
$$

where $y^{D}=h\left(y^{T}\right)$ corresponds to the endowments of tradable goods in default periods. After defaulting, the sovereign is temporarily excluded from issuing debt. We assume $\theta$ to be the probability that the sovereign regains full access to international credit markets.

International investors are risk-neutral and have an opportunity cost of funds given by $\rho$, which denotes the risk-free rate denominated in the price of tradable goods. Investors will choose the debt and reserve prices, $q^{D}$ and $q^{R}$, which depend on the perceived likelihood of default and currency depreciation. For these investors to be indifferent between the riskless asset and lending in a country's non-tradable goods denomination, it must be the case that,

$$
q_{t}^{D}=\frac{1}{(1+\rho)} E_{t}\left[\left(1-d_{t+1}\right) \frac{e_{t}}{e_{t+1}}\right],
$$

and

$$
q^{R}=\frac{1}{1+\rho}
$$

where $d_{t+1} \in\{0,1\}_{t}$ is the occurrence (or not) of default, which is endogenously determined and depends on the sovereign's incentives to repay the debt. Note (5) is a version of the uncovered interest parity condition that considers the possibility of default.

Because the government chooses debt and reserve levels, the problem of the households is intratemporal, and has the sole role of determining the real exchange rate. Individual household maximization equates the relative marginal utility of tradables to nontradables to their relative prices, 


$$
e_{t}=\frac{\omega}{(1-\omega)}\left(\frac{c_{t}^{N}}{c_{t}^{T}}\right)^{1+\eta}
$$

The market-clearing condition for non-tradable goods is:

$$
c_{t}^{N}=y_{t}^{N}
$$

The timing of the decisions is as follows. In the beginning of each period, the government starts with debt level $D_{t}$ and reserve level $R_{t}$ and receives endowments $y^{T}$ and $y^{N}{ }_{t}$. It faces the reserve price schedule $q^{R}\left(s_{t}, R_{t+1}, D_{t+1}\right)$, bond price schedule $q^{D}\left(s_{t}, R_{t+1}, D_{t+1}\right)$, and real exchange rate price schedule $e\left(s_{t}, R_{t+1}, D_{t+1}\right)$. Taking these schedules as given, the government simultaneously makes three decisions. It chooses (i) the next level of reserves, $R_{t+1}$, (ii) whether to default on the debt, and (iii) if it decides not to default, the next level of debt, $D_{t+1}$.

The model described is a stochastic dynamic game. We focus exclusively on the Markov perfect equilibria, whereby the government does not have commitment and players act sequentially and rationally.

Note that international investors and households are passive, and their actions can be completely described by equations (5), (6), and (7). To write the government problem recursively, let $v^{G}$ denote the value function if the sovereign decides to maintain a good credit history this period ( $G$ stands for good credit history), and $v^{B}$ the value function if the sovereign decides to default ( $B$ stands for bad credit history). The value of being in good credit standing at the start of a period can then be defined as

$$
v=\operatorname{Max}\left\{v^{G}, v^{B}\right\}
$$

This indicates that the sovereign defaults if $v^{G}<v^{B}$. The value function $v^{G}$ can be written as:

$$
v^{G}\left(s_{t}\right)=\operatorname{Max}\left\{u\left(c_{t}^{T}, c_{t}^{T}\right)+\beta E v\left(s_{t+1}\right)\right\}
$$


subject to (3), and the value function $v^{B}$ as:

$$
\left.v^{B}\left(s_{t}\right)=\operatorname{Max}\left\{u\left(c_{t}^{T}, c_{t}^{T}\right)+\beta \mid \theta E v^{G}\left(s_{t+1}\right)+(1-\theta) E v^{B}\left(s_{t+1}\right)\right]\right\},
$$

subject to (4).

The recursive equilibrium is defined by the set of policy functions for government asset holdings and default choice and the price functions for domestic bonds, reserves, and the real exchange rate such that, (i) taking the price functions as given, the government policy functions satisfy the government optimization problem, and (ii) prices of domestic bonds, reserves, and the exchange rate are consistent with the government's decisions.

This definition of equilibrium, identical to that of Arellano (2008) and Alfaro and Kanczuk (2005, 2009), among many others, reflects a game played by a large agent (the government) against many small agents (the continua of investors and households). It implies that the government internalizes the effects of its actions over the prices. In our model, the government internalizes the effect of its asset holdings over the real exchange rate.

\section{Quantitative Analysis}

We solve the model numerically to evaluate its quantitative predictions in relation to the accumulation of debt and reserves, the occurrence of default events and the business cycle properties of the exchange rate.

\subsection{Calibration}

One challenge in conducting quantitative analysis is that emerging countries only began to issue relevant amounts of domestically-denominated bonds in the middle of the past decade. The data time span of the current regime, especially concerning episodes of default, is relatively small. In Brazil, for example, the last default episode was between 1983 and 1990 (Reinhart, 2010). 
We address this problem by calibrating some of the parameters using a much longer time horizon, during which international debt was denominated mainly in foreign currency. In transforming our economy to consider the case in which bonds were denominated in foreign currency, we assume the country budget constraint to be given by:

$$
c_{t}^{T}+\frac{c_{t}^{N}}{e_{t}}+q_{t}^{R} R_{t+1}-q_{t}^{B} B_{t+1}=y_{t}^{T}+\frac{y_{t}^{N}}{e_{t}}+R_{t}-B_{t},
$$

rather than equation (3).

This is effectively the case considered by Alfaro and Kanczuk (2009), in which $B$ denotes holdings of foreign bonds denominated in foreign currency. As above, in the case of a debt default, reserves $R$ continue to be held and can be used to smooth consumption. We proceed with calibration by considering annual data since 1965 .

We set the international interest rate $\rho=0.04$ and the inter-temporal substitution parameter $\sigma=2$, as is usual in real business cycle research in which each period corresponds to one year (see Kanczuk, 2004). Due to considerable disagreement over the intratemporal elasticity of substitution between tradable and non-tradable goods (Akinci, 2011), we make the elasticity equal to one (the middle of the many possible estimations), and, for that, set $\eta=$ 0 . Our results are robust to many other parameter values. For the weight of tradables, we use the share of output that corresponds to industry and agriculture, and set $\omega=0.35$, which is also consistent with literature estimations.

Because non-tradable consumption goods cannot be smoothed, we focus on the case in which shocks are exclusively external, that is, on the tradable endowment. ${ }^{2}$ We thus make $y^{N}=1$ for all periods. We then set $y^{T}{ }_{t}=\exp \left(z^{T}{ }_{t}\right)$, and assume that $z^{T}{ }_{t}$ can take a finite number

\footnotetext{
${ }^{2}$ Since the consumption of non-tradeable goods must be always equal to the non-tradeable endowment, domestic shocks cannot be smoothed out (unless one considers additional policy tools such as fiscal policy, for example). Different debt and reserve levels could still affect allocations due to the valuation effects, albeit quantitatively small, that result from the exchange rate movements.
} 
of values and that it evolves over time according to a Markov transition matrix with elements $\pi^{T}\left(z_{i}^{T}, z_{j}^{T}\right)$; that is, the probability that $z_{t+1}^{T}=z_{j}^{T}$, given that $z_{t}^{T}=z_{i}^{T}$, is given by the matrix $\pi$ element of row $i$ and column $j$.

We calibrate the technology state $z^{T}$ by considering the (logarithm) of GDP to follow an $A R(1)$ process; that is, $z_{t+1}^{T}=\alpha z_{t}^{T}+\varepsilon_{t+1}$ where $\varepsilon_{t} \approx N\left(0, \sigma_{\varepsilon}{ }^{2}\right)$. We obtain $\alpha=0.85$ and $\sigma=$ 0.12. The apparently high value of the standard deviation reflects the fact that the tradable sector corresponds to roughly one-third of total output. To make the model consistent with the data, the volatility of the tradable sector must thus be approximately three times that of total output. As an indirect indication of consistency, we note that the volatility of the industry and agriculture output is three times as high as the Brazilian GDP.

We discretize this technology state into nine possible values, spaced such that the extreme values are three standard deviations away from the mean. We also discretize the space state of debt and reserves enough to avoid spurious results.

Setting the probability of redemption at $\theta=0.5$ implies an average stay in autarky of two years, in line with estimates by Gelos et al. (2011). Direct output costs are modeled from default and assumed to be asymmetric. The endowments of tradable goods in default periods are given by $h\left(y^{T}\right)=y^{D E F}$ in case $y^{T}>y^{D E F}$, and $h\left(y^{T}\right)=y^{T}$ in case $y^{T} \leq y^{D E F}$. Setting $y^{D E F}=$ $0.85 y^{T}$ implies that tradable output costs of defaulting equal $15 \%$, with the relatively large number again reflecting the fact that the tradable sector corresponds to one-third of the economy. The choice of output costs affects the probability of default. Thus, we calibrate output costs in order to make the interest spread in the simulations equal to the average level observed in the data, $6.8 \%$.

To obtain reasonable levels of debt in equilibrium, we set the intertemporal factor at the relatively low value of $\beta=0.80$, which is common practice in debt models (Alfaro and 
Kanczuk, 2009). This calibration of $\beta$ also makes the average debt service - defined as $B_{t}-q_{t}^{B} B_{t+1}-$ equal to its observed levels, which is $3.3 \%$ of GDP. (This happens because the interest spread level was also matched).

Table 1 summarizes the parameter values.

Table 1: Calibration

\begin{tabular}{lcc}
\hline Parameter & Calibration & Data matched \\
\hline Technology autocorrelation & $\alpha=0.85$ & GDP AR(1) process \\
Technology standard deviation & $\sigma_{\varepsilon}=0.12$ & GDP AR(1) process \\
Fraction of tradeableas & $\omega=0,35$ & Share of industry \& agriculture \\
Probability of redemption & $\theta=0.50$ & Duration of each default \\
Output costs & $y^{D E F}=0.85 y^{T}$ & Interest Spread \\
Risk aversion & $\sigma=2$ & Brazilian Business Cycle \\
Risk free interest rate & $\rho=0.04$ & Brazilian Business Cycle \\
Discount factor & $\beta=0.80$ & Debt \\
\hline
\end{tabular}

\subsection{Simulation results}

We first simulate our economy under the assumption that debt is denominated in foreign currency. For the chosen parameters, the invariant distribution displays $48 \%$ of GDP of debt and a $6.1 \%$ frequency of default (case (i) in Table 2). These numbers align closely with the historical data for Brazil and other emerging countries presented in many other papers. The equilibrium level of reserves is zero, a reincarnation of Alfaro and Kanczuk's (2009) result in a model with two sectors (but shocks in only one).

As discussed extensively in that paper, there is a potential role in this setup for reserves to smooth consumption when a country is excluded from international markets. But, because reserve holdings reduce the sustainability of debt, quantitatively their optimal 
holding is zero. The optimal government policy is to hold (foreign-denominated) debt and default in extremely bad times.

Table 2: Invariant Distribution Properties

\begin{tabular}{lccc}
\hline & Case (i) & Case (ii) & Case (iii) \\
\hline Foreign Denominated Debt (\% GDP) & 48.0 & - & - \\
Locally Denominated Debt (\% GDP) & - & 9.8 & 28.6 \\
International Reserves (\% GDP) & 0.0 & - & 24.0 \\
Probability of Default (\%) & 6.1 & 0.4 & 0.4 \\
Std.Dev. (y) (\%) & 2.8 & 2.8 & 2.8 \\
Std.Dev. (e) (\%) & 26.2 & 7.5 & 4.2 \\
Std.Dev.(e) / Std.Dev.(y) & 9.4 & 2.7 & 1.5 \\
Std.Dev. (c) (\%) & 2.0 & 0.5 & 0.3 \\
Std.Dev. (r) (\%) & 2.3 & 0.2 & 0.2 \\
Sdt. Dev.(nx/y) (\%) & 2.4 & 3.8 & 3.4 \\
Corr (e, y) & -.99 & -.90 & -.17 \\
Corr (c, y) & .99 & .90 & .17 \\
Corr (r, y) & -.79 & -.79 & -.79 \\
Corr (nx/y, y) & .99 & .99 & .99 \\
\hline
\end{tabular}

Notes: $\mathrm{y}, \mathrm{c}, \mathrm{e}$ and $\mathrm{r}$ denote, respectively, output, consumption, exchange rate and interest rate spread.

As an intermediate step, assuming the government cannot hold reserves (case (ii)), we simulate the economy with locally-denominated bonds. We obtain, in this case, that the government holds a fairly small amount of debt (9.8\% of GDP) and virtually does not default. Note that the volatility (standard deviation) of the exchange rate drops from $26.2 \%$ in the case of foreign-denominated debt, and to $7.5 \%$ in the case of domestically-denominated debt with no reserves. Thus, even without resorting to default, domestic denomination results in more consumption smoothing.

The level of domestic-denominated debt is small because consumption smoothing can be attained even without default. Defaulting allows to smooth consumption but is costly: the 
exclusion of markets and output drop itself. Since the benefit of smoothing is not needed, the sovereign opts to choose a level of debt in which she can resist defaulting.

When we simulate the economy with locally-denominated bonds, but allow the government to hold positive amounts of reserves (case (iii)), we obtain that, in the invariant distribution, the economy displays $28.6 \%$ of GDP in (locally denominated) debt, with $24 \%$ of GDP in reserves. As in case (ii), the government virtually does not resort to default as a means to smooth consumption. Note, also, that the volatility of consumption drops even more, with the standard deviation of the exchange rate falling to 4.2 percent.

The intuition for holding both (domestically-denominated) debt and reserves, developed in Section 2, is to allow for consumption smoothing across both states and time. But the experiment with the full-fledged model yields novel results.

In the two-period model, the optimal policy was to accumulate infinite amounts of debt and reserves. In the general model, default incentives and the related issue of debt sustainability reduce the amount of optimal debt and reserves. That they may, in fact, be smaller than anticipated suggests that this scheme for smoothing consumption is fairly powerful.

A second insight is that the accumulation of reserves is not a problem in terms of reducing the sustainability of debt when debt is in local currency. The experiment shows the proposed scheme to be, in fact, sustainable in the sense that the government (almost) never defaults.

Put differently, in both the foreign-denominated and locally-denominated debt experiments, international reserves play a role when a country is excluded from capital markets. However, this role reduces the amount of debt that is sustainable, triggering defaults, which are costly. When debt is foreign-denominated, Alfaro and Kanczuk (2009) obtain that the optimal level of reserves is zero. This paper indicates that, when debt is 
domestically-denominated, reserves are very useful, owing to their valuation effect, which helps smooth consumption.

Given that the interest earned from their reserves is much lower than that paid on their debt, the reserve accumulation policy of emerging economies seems sub-optimal. For example, Brazil's total government debt (domestic and international) in 2011 was approximately $60 \%$ of GDP and paid annual interest of about $12 \%$. Its holdings of international reserves, at $15 \%$ of GDP, earned interest of approximately $2 \%$ per year. Over the last years, many pundits argue that international reserves are too costly, and that Brazil should use them to reduce outstanding debt.

According to our model, the logic of accumulating both reserves and domesticallydenominated debt is precisely that it is costly during good periods. When an international shock is favorable, debt service is higher and consumption is reduced, when unfavorable, debt service is reduced and consumption increases. When the whole invariant distribution of shocks is taken into account, a country will enjoy a more stable level of consumption.

Note that in the proposed construction, the level of reserves remains high during unfavorable periods. The idea is not to buy consumption goods that deplete the stock of reserves, but rather to maintain a constant reserve stock that serves as insurance by increasing the stabilizing effect of domestic-denominated debt. Contrary to the usual argument in policy circles, reserves are thus not insurance that can be "used" in bad times.

In fact, the optimal policy function is to hold the amount of debt and reserves constant in the relevant region, regardless of the period state. For this reason, we opted not to depict the debt and reserve policy functions since they are just simple horizontal lines.

To better grasp the mechanism of consumption smoothing without changing debt and reserve holdings, we proceed as in the two-period model. Consider the household budget 
constraint (3) after plugging in the non-tradable goods market clearing condition, and assuming debt and reserves holdings are constant:

$$
c_{t}^{T}=y_{t}^{T}+\left(1-q_{t}^{R}\right) R-\left(1-q_{t}^{D}\right) \frac{D}{e_{t}} .
$$

In good states of nature, endowment $y^{T}$ is higher, which makes consumption also higher. However, even if reserves and debt holdings (and interest rates) are constant, the valuation effects of the exchange rate $e_{t}$ can also affect consumption levels. If it is the case the exchange rate appreciates in good periods (depreciates in bad periods), this valuation effect tends to offset the endowment effect. Equation (7), which equates the relative marginal utility of tradables to non-tradables to their relative prices, predicates exactly that. That is, in good periods the exchange rate is smaller (more appreciated) and therefore consumption does not increase as much.

Notice that reserve holdings are kept constant, and that debt holdings are kept constant in domestic units. However, debt holdings in foreign currency change affect the consumption of tradable goods. In other words, it is the change in debt holdings in foreign currency that offsets the endowment shock and makes consumption smoother.

The finding that debt and reserve holdings do not vary with the state of nature is a striking result. We investigated further the generality of this result by considering alternative parameterizations and allowing for finer grid around the optimal values. We found that this invariance result is very robust and, in this sense, seems more qualitative than quantitative. The essential intuition for the result is that the stabilization effect of issuing local-currency debt provides sufficient consumption smoothing so that there is no need to change the levels of debt and reserves.

Early literature on sovereign debt has proposed two alternative devices to smooth consumption. One is contingent debt, which is to vary debt holdings depending on the state 
(e.g., Eaton and Gersovitz (1981)). The other is contingent service, where debt holdings are kept constant, but debt services vary with the state of nature (e.g. Grossman and Van Huyck (1988)). ${ }^{3}$ Adding to that literature, Grossman and Han (1999) show that contingent service models allow for more consumption smoothing than contingent debt models.

More recent literature (e.g. Arellano (2008)) considered models in which contingent debt and contingent services were simultaneously possible. An interesting result of this literature is that, in equilibrium, only contingent services are used to smooth consumption. In contrast, debt tends to be used primarily to front load consumption. A common result in this literature is that debt holdings are lower in bad times (see Kanczuk and Alfaro (2009)). That is, changes in the debt level make consumption less smooth.

As in recent literature, the model in this paper assumes both contingent debt and contingent services are possible. A novelty is that there are two instruments to perform contingent service. One is the traditional option to default; the other is valuation effects via exchange rate changes.

The finding that debt and reserve holdings do not vary with the state of nature is striking at first sight. But it can be seen as a reincarnation of the result that only contingent service is used for consumption smoothing. The stabilization effect of issuing local-currency debt provides sufficient consumption smoothing.

\subsection{Comparison with Brazilian Data}

We now compare the model's outcomes with recent data from Brazil. Figure 3 plots the evolution of government holdings of international reserves and foreign- and domestically-

\footnotetext{
${ }^{3}$ That is, consumption smoothing is achieved by making service contingent on the realization of income: the sovereign services its debt in full only when it realizes high income and faults either partially or fully when it realizes low income.
} 
denominated debt. These assets (or liabilities) could potentially be held against both the Brazilian private sector and the rest of the world.

In our model, only the government is assumed to be able to hold international assets. However, the position of the full country (government and private sector) against the rest of the world is, in fact, the closest concept to be contrasted with the model. The challenge in doing so is the absence of comprehensive data about the denomination of private sector holdings.

\section{Figure 3: Government Holdings (\% GDP)}

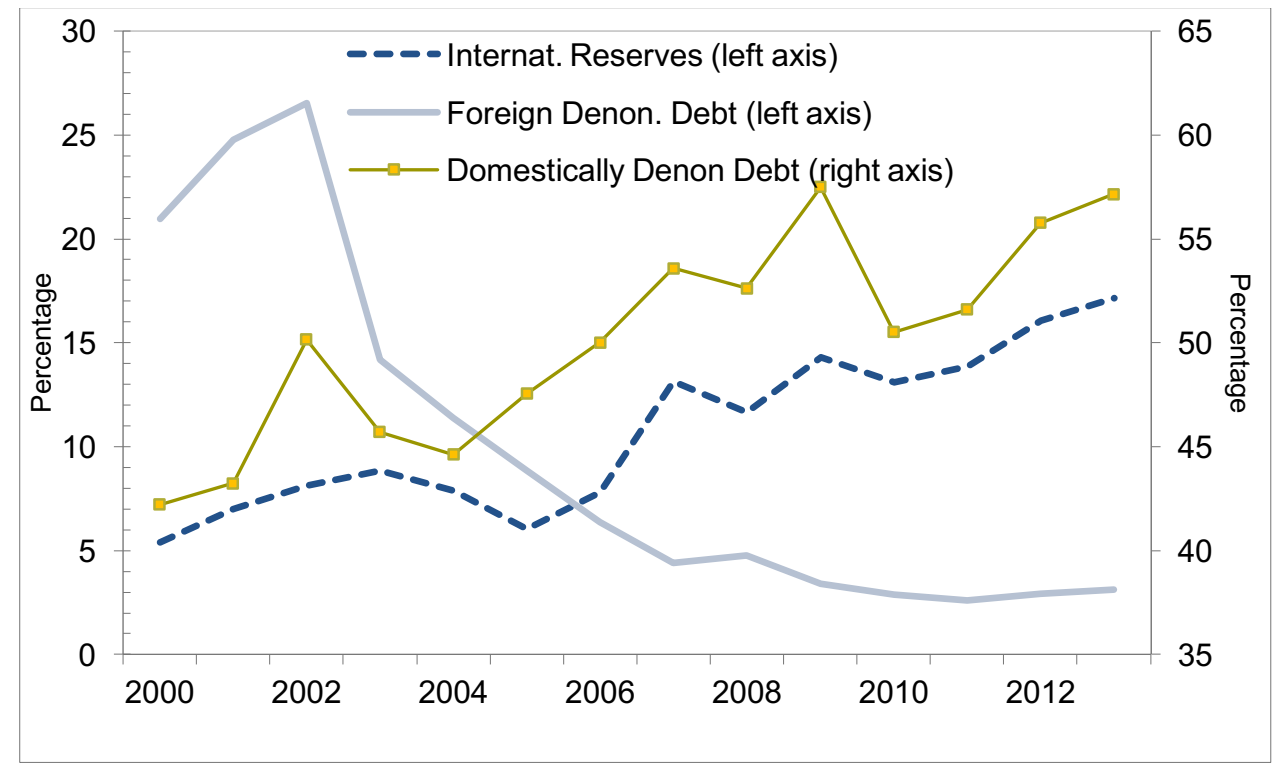

Source: Brazilian Central Bank.

Although some information about private sector debt holdings is available, it is common practice for firms to change the denomination of debt using market derivatives. It is similarly common for foreigners to use derivatives to gain exposure to the Brazilian currency and invest in carry trade strategies. Because these derivatives to swap currencies are often traded over the counter, it is impossible to assess their dimension (see Benetrix, Lane and 
Shambaugh (2015)). ${ }^{4}$ Given the lack of comprehensive data, we assume international reserves and foreign-denominated government debt to roughly correspond to the country's position in relation to the rest of the world.

The case of domestic-denominated bonds is more complicated. We know that before 2003, foreign exposure to Brazilian currency debt was quite small. ${ }^{5}$ Post-2002, because the increase in debt was concomitant with the accumulation of reserves, as depicted in Figure 3, it is natural to assume foreigners to be responsible for a large fraction of it.

Table 3: Brazilian Data

\begin{tabular}{lcc}
\hline & 1996 to 2005 & 2006 to 2014 \\
\hline Foreign Denominated & Debt & Assets (Reserves) \\
Locally Denominated & 0 & Debt \\
Std. Dev. (y) (\%) & 3.0 & 2.2 \\
Std. Dev. (e) (\%) & 35.9 & 12.3 \\
Std. Dev. (e)/Std. Dev. (y) & 11.8 & 5.6 \\
Std. Dev. (c) (\%) & 6.0 & 3.3 \\
Sdt. Dev.(r) (\%) & 3.8 & 1.4 \\
Sdt. Dev.(nx/y) (\%) & 2.9 & 2.5 \\
Corr (e, y) & -0.90 & -0.87 \\
Corr (c, y) & 0.92 & 0.69 \\
Corr (r, y) & -0.69 & 0.14 \\
Corr (nx/y, y) & -0.82 & -0.58 \\
Mean (r) (\%) & 7.7 & 1.4 \\
\hline
\end{tabular}

Note: $y, c, e, r$ and $n x$ denote output, consumption, exchange rate, interest spread and net exports.

Table 3 summarizes the data. Rather than guessing the holdings of assets and liabilities, we indicate the net position in each denomination. Before 2006, there was virtually

\footnotetext{
${ }^{4}$ Anecdotal information indicates that even large firms that issue bonds denominated in dollars hedged most of their currency exposure after the substantial depreciation in 1999 (Central Bank of Brazil (2015)).

${ }^{5}$ In 2002, the Brazilian five-year CDS, which measures the risk of dollar denominated debt, was as high as 4,000 basis points. In periods with such risk of default, it is highly unlikely that foreigners would hold local currency.
} 
no local-denominated external debt. After 2006, holdings of reserves were higher than holdings of foreign-denominated debt. Thus, the net position of foreign-denominated securities switched from debt (liabilities) to assets (reserves).

The comparison between Table 2 and Table 3 requires some discussion. As there was no available data on the consumption of tradables and non-tradables, we chose the exchange rate as the primary variable to contrast with the model. Due to a small sample, a single crisis could imply differing output volatilities. We therefore calculated the ratio between the exchange rate standard deviation and output deviation to make the comparison of the model and data more robust.

Our argument is that with debt redemption, the Brazilian economy should move from case (i) in Table 2 (foreign-denominated debt) to case (iii) in the same table (domesticallydenominated debt and international reserves). The country seems to be in the process of changing from one steady state to the other, whereas Table 2 shows the economy to already be in the steady state invariant distribution.

We propose considering the 2006-2014 time-horizon of Table 3 data as an intermediate step in the transition from case (i) to case (iii) in Table 2. Interpreted this way, the model accounts for the exchange rate's cyclical behavior reasonably well. The ratio of volatility of the real exchange rate to that of output dropped by half, from 11.8 to 5.6 (Table 3). According to our model, this ratio should drop from 9.4 to 1.5 if the country moves from one steady state to the other (Table 2). Brazil, however, is still far from converging on the steady state. During the 2006-2014 period, Brazil's holdings of international reserves were $13.4 \%$ of GDP. In the proposed steady state, these holdings would reach $24 \%$ of GDP.

Table 3 additionally depicts the correlation of the exchange rate and output. For the two periods considered, the correlation was -0.90 and -0.87 . In our model, there being shocks only to tradable goods, this correlation is equal to -0.99 in case (i). A simple way to reduce 
this correlation would be to add (uncorrelated) shocks to the non-tradable sector. We nevertheless adopt this comparison to support our hypothesis that non-tradable sector shocks are not a quantitatively important factor in our analysis. Consumption smoothing by itself makes this correlation very low, once domestic debt is considered.

For completeness, Table 3 also reports consumption standard deviations, as a secondary indication of the volatility reduction, and the correlation between net exports (trade balance) with output. We observe that the volatility of consumption also drops in Brazil, both in absolute value and as a fraction of GDP volatility. ${ }^{6}$ However, the mere fact that the volatility of consumption is a lot higher than GDP volatility raises questions of the use of consumption in the place of exchange rates. ${ }^{7}$

The moments related to net exports suffer from a related problem. As there are no investments in our endowment economy, the correlation of net exports with output is intimately related to the volatility of consumption. Thus, in the model, consumption smoothing implies that net exports are very procyclical. In contrast, as Table 3 shows, the trade balance is countercyclical in the data. ${ }^{8}$

\footnotetext{
${ }^{6}$ Measurement problems with Brazilian data render consumption volatility a particularly noisy information. In Brazil, as in other emerging countries, there is no direct measure of inventories. Total GDP is then calculated from the supply side. In order to make GDP from the demand side equal to the supply side calculation, inventory changes (and any other mismeasurements) are implicitly added to the consumption component. In other words, consumption is obtained by the residual. As a consequence, the reported consumption component becomes less reliable and more volatile than expected. In the US national accounts statistics, in contrast, inventory changes are measured and reported. Consumption is more informative and is less volatile than GDP, as usual theory suggests. To illustrate the problem, we can make the US data comparable with Brazil, by adding the change in inventories and measurement residual to the original U.S. consumption series. The resulting consumption series becomes more volatile than GDP, as in Brazil. According to this perspective, consumption volatility in the Brazilian data is not a reliable indicator. As a consequence, the consumption volatility generated by the model, which is smaller than GDP volatility, should not be considered a limitation of the model.

${ }^{7}$ Alternatively, García-Cicco, Pancrazi and Uribe (2010) modify the basic real business cycle model in order to match Mexican and Argentinean data moments. One of their findings is that preference shocks are responsible for most of the excess volatility of consumption over output in these countries. Applying the same logic to the model here, one could add preference shocks in order to increase consumption volatility. However, this, not being the focus of the paper, would not add to our understanding of the mechanisms proposed, but would add computational complexity.

${ }^{8}$ This is a direct consequence of having an endowment economy. There is a long literature (e.g. Backus, Kehoe and Kydland (1992)) showing how the steep reaction of investments to positive shocks can make net exports countercyclical in simple models. In other words, there is a standard way to match this feature of the data. However, for computational simplicity, this paper is abstracting from this issue.
} 
Finally, Table 3 reports the correlation between the spread and output. In the first period the correlation is negative, as expected. In the second period it becomes positive but is very small. This happens because, with the recent reduction of risk, spreads converge to fairly small values and become largely irrelevant for the understanding of other variables.

\subsection{Evidence from other Emerging Countries}

We now look at empirical evidence for other emerging countries. As we mentioned in the introduction, the accumulation of domestic-denominated debt in conjunction with reserves is becoming a ubiquitous phenomenon. This generates several questions. Are the countries that accumulate more debt the ones that are more susceptible to international shocks? Has the volatility of the exchange rate dropped more in countries that accumulated more debt?

Although a formal analysis is beyond the scope of this paper, in Table 4 we report selective statistics for countries depicted in Figures 1 and 2, for which Moody's study offers complete data. As a word of caution, since the time span covered is very short, it becomes statistically difficult to capture changes. We opted to define two periods - the first containing the years from 2000 to 2004 , the second defined by the period 2010 to 2014 - to calculate the averages of the variables. We then obtain the change in the stock of debt, the stock of reserves and the standard deviation of the exchange rate between these two periods.

Even though the data sample is very small, this exercise reveals results that are consistent with our hypothesis. In particular, the correlation between (domestically denominated) debt accumulation and exchange rate volatility reduction is positive and equal to 0.3. It is also the case that the correlation of debt accumulation and reserve accumulation is positive (equal to 0.4 ). On the other hand, we note that for many countries there was an increase in exchange rate volatility, in spite of debt and reserves accumulation. We also note 
that the correlation between reserve accumulation and volatility reduction is slightly negative (equal to -0.1).

We believe the best way to look at table 4 is to divide the countries into those for which the exchange rate was very volatile (Brazil, South Africa and Turkey), and those for which the exchange rate was already fairly stable in the first period considered (Philippines, Thailand, Peru, China). In the countries for which the exchange rate was very volatile, the accumulation of (domestically denominated) debt and reserves had an important effect and caused a reduction in volatility. In countries in which the exchange rate was already stable, accumulation did not make a significant difference.

Table 4: Emerging Countries Debt, Reserves and Exchange Rate Facts

\begin{tabular}{lcccccccccc}
\hline & $2000-14$ & $2000-04$ & $2010-14$ & $2000-04$ & $2010-14$ & $2000-04$ & $2010-14$ & Change & Change & Change \\
& Corr $(e, y)$ & Debt & Debt & Reserves & Reserves & S.D. $(e)$ & S.D. $(e)$ & Debt & Reserves & S.D. $(e)$ \\
\hline Brazil & -0.90 & 45.2 & 54.7 & 7.5 & 15.6 & 20.6 & 13.2 & 9.5 & 8.1 & -7.4 \\
S. Africa & -0.41 & 32.6 & 38.1 & 4.8 & 10.9 & 20.2 & 14.4 & 5.5 & 6.1 & -5.8 \\
Turkey & -0.59 & 20.9 & 27.0 & 11.8 & 13.4 & 17.8 & 10.3 & 6.0 & 1.6 & -7.5 \\
Chile & -0.68 & 1.2 & 9.2 & 19.9 & 14.8 & 9.9 & 9.8 & 8.0 & -5.1 & -0.2 \\
Mexico & -0.88 & 12.9 & 23.3 & 7.4 & 12.5 & 8.5 & 11.0 & 10.4 & 5.1 & 2.5 \\
Colombia & -0.45 & 26.3 & 24.0 & 11.2 & 9.6 & 7.6 & 8.7 & -2.2 & -1.6 & 1.1 \\
Philipines & -0.54 & 33.7 & 25.9 & 18.6 & 27.6 & 4.6 & 5.8 & -7.8 & 9.0 & 1.2 \\
Thailand & -0.56 & 20.0 & 30.2 & 28.6 & 46.6 & 4.5 & 4.9 & 10.2 & 18.0 & 0.4 \\
Peru & -0.72 & 5.6 & 9.6 & 16.3 & 29.5 & 2.8 & 3.7 & 4.0 & 13.2 & 0.9 \\
China & -0.24 & 14.8 & 29.3 & 20.7 & 41.5 & 0.0 & 1.8 & 14.4 & 20.8 & 1.7 \\
Mean & -0.60 & 21.3 & 27.1 & 14.7 & 22.2 & 9.7 & 8.3 & 5.8 & 7.5 & -1.3 \\
Median & -0.57 & 20.5 & 26.4 & 14.0 & 15.2 & 8.1 & 9.3 & 7.0 & 7.1 & 0.6 \\
\hline
\end{tabular}

Notes: $y$ and e denote, respectively, output and exchange rate.

A similar point can be made about the choice of exchange rate regime. Since most of the real exchange rate volatility comes from the nominal exchange rate, fixed exchange rate regimes result in very low (real) exchange rate volatilities. One thus expects that, in these regimes, the correlation between debt (or reserve) accumulation and the exchange rate 
volatility is not informative. In the sample considered, even though all countries have de jure flexible regimes, some have what de facto resembles a fixed regime (Levy-Yeyati and Sturzenegger (2003)). This is a reason to focus on the countries with higher volatility. In those countries, the accumulation of debt (and reserves) had an important effect in reducing exchange rate volatility.

\section{Robustness and Discussion}

\subsection{Volatility of Exchange Rate}

In our model, as in other standard exchange rate models, the volatility of the exchange rate is directly linked to the volatility of the ratio of the consumption of tradable and nontradable goods. If the volatility of consumption is much higher than that observed in the data, our model generates only reasonable levels of exchange-rate volatility. Adding to this puzzle, Engel (1999) shows movements in the U.S. exchange rate to be driven almost exclusively by changes in prices of tradable goods, which are usually assumed to be equal across countries.

Burstein, Neves, and Rebelo (2003), addressing these issues in the context of exchange-rate stabilization, introduce in an otherwise standard model a distribution sector that can dramatically improve the model's performance. Rather than adding a new sector to our model, we invoke their claim that modifying preferences in a standard model can mimic the introduction of distribution costs.

We modify, in particular, the utility function, making the share of tradable goods $\omega=$ 0.10. As above, we find the optimal policy to be the accumulation of reserves in conjunction with locally denominated debt, and this strategy to be effective at smoothing consumption across both different states of nature and time. The only difference between the results of this experiment and the one in Section 4 is quantitative. In this alternative economy, the levels of 
local-currency debt and reserves as a percentage of GDP are, respectively, $10.4 \%$ and $3.2 \%$. Thus, the decrease in the importance of the tradable sector implies, as expected, a reduction in debt and reserve accumulation.

\subsection{Shocks to Non-Tradeable Endowment}

As discussed in the calibration of the model, we opted to focus on the case in which shocks are exclusively external (tradable). Domestic (or non-tradable) shocks are not essential to the analysis, as they cannot be smoothed out (consumption of non-tradable goods must be always equal to the non-tradable endowment). However, one can investigate if by adding shocks to the non-tradable endowment there is substantial improvement of the model fitness.

Table 5 reports the results of such experiments. Its first two lines show the exchange rate and output moments for the Brazilian data in the two periods considered. The next four rows show the moments from model simulations. The third line corresponds to case (i) of section 4.2 , in which there is only foreign denominated debt and there are only shocks to tradeable endowment. The fifth line corresponds to case (iii) of section 4.2 , in which there are locally-denominated debts and reserves, but again only tradable shocks. Lines third and sixth are extensions of the third and fifth lines (respectively), when there are shocks both to tradables and to non-tradable endowment.

Note that the correlation between exchange rate and output was -0.90 and -0.87 in the two periods considered. In contrast, in our model, there being shocks only to tradable-goods, this correlation is equal to -0.99 when there is only foreign-denominated debt (third line of Table 5).

In order to reduce this correlation, we then add (uncorrelated) shocks to the nontradable sector. We find that by having the volatility of non-tradable shocks equal to one third 
of the volatility of the tradable shocks, we can exactly match this dimension of the data. This is reported in the fourth line of Table 5. Notice that there is no substantial change in the volatility of the exchange rate.

Table 5: Exchange Rate Moments

\begin{tabular}{lcc}
\hline & $\begin{array}{c}\text { Std. Dev.(e)/ } \\
\text { Std. Dev. }(y)\end{array}$ & Corr $(e, y)$ \\
\hline Brazil 1996-2005 & 11.8 & -0.90 \\
Brazil 2006-2014 & 5.6 & -0.87 \\
Only Tradables shocks, Foreign Denominated Debt & 9.4 & -0.99 \\
Non-Tradables shocks, Foreign Denominated Debt & 9.6 & -0.87 \\
Only Tradables shocks, Locally Denominated Debt & 1.5 & -0.17 \\
Non-Tradables shocks, Locally Denominated Debt & 1.4 & 0.25 \\
\hline
\end{tabular}

We then consider the case with locally-denominated debt. When there are only shocks to tradable endowment, the correlation between exchange rate and output is much smaller, although still negative, as in the data. However, when shocks in non-tradable goods are added, this correlation becomes positive.

The conclusion of this experiment is that although the inclusion of non-tradable shocks can improve one dimension of the model, it worsens the other dimension considered in this section.

\subsection{Reserve Accumulation and Exchange Rate Management}

A branch of the literature argues that reserve accumulation is a means of keeping the exchange rate depreciated, thereby helping to protect a country's industry and stimulate exports (Dooley et al., 2003). In this paper we do not consider mercantile considerations for reservation accumulation. For example, as the commodity boom ended and growth slowed, 
some countries have used their international reserves to maintain their exchange-rate peg. However, this has clearly not been the main driver for all countries. Brazil, for example, maintained roughly the same reserve management policy independent of commodity prices.

Notice that while in the present paper, reserves are used to smooth the volatility of the exchange rate, in the literature on reserves and export-led growth, reserves are used to influence the average value of the exchange rate. That is, in our model, the rationale for reserve accumulation is to smooth consumption of tradable goods. But as a direct consequence, the exchange rate is also smoothed. In particular, the exchange rate does not need to appreciate as much in good times due to the valuation effects associated with the accumulation of reserves.

\subsection{Rationale for Debt Redemption}

In our model, debt redemption, or the possibility of a country issuing external debt denominated in local currency, implies fewer occurrences of default. A related issue considers why emerging countries were unable to issue domestically-denominated external debt previously, such as during the 1980s and into the 1990s. Although a complete investigation is beyond the scope of this paper, we conjecture that there were two reasons for recent debt redemption.

One possibility is that investors could not identify the type of government issuing the bonds. As Alfaro and Kanczuk (2005) argue, sovereign-default episodes (delays, rescheduling, etc.) seem consistent with reputation building. This, in turn, is consistent with the existence of different types of governments, including those that would default independent of the state of nature ("inexcusable defaults", in the language of Grossman and Van Huyck (1988)). Lenders, when extracting information from the default in order to set the next period's interest rate, most likely will consider the possibility that in this period the 
sovereign was of the "bad" type, and charge higher interest rates. It is possible that risk increased sufficiently to shut down the market. As the type of government in control became clearer and the risk was reduced, international investors became more disposed to buy debt issued in local markets.

A second, related issue is inflation. Inflation and inflation volatility were extremely high in Latin America during the 1980s, making returns on domestic-denominated bonds very risky for international investors, possibly so high that investor appetite for this type of asset was insufficient for the existence of the market.

\subsection{Private-Sector Debt}

In our model, debt is issued exclusively by the benevolent government; households (i.e., the private sector) cannot issue debt and choose their intertemporal consumption. This assumption raises two issues. First, the analysis would be unchanged were private sector debt to be included, assuming no distortions or other imperfections (taxes, externalities, time inconsistency issues) that could drive a wedge between the objectives of the benevolent government and those of the households. Second, in the event that the objectives of the government and the households do conflict, the government could attempt to offset, perhaps even prohibit, household debt and reserve accumulation by creating rules and changing the law. Thus, unless political economy issues are considered, the assumption that households cannot issue debt is not crucial to the analysis.

As mentioned before, since firms often use over-the-counter derivatives to change their debt denomination, data on private debt is unreliable for assessing net positions. These considerations notwithstanding, due to the recent Real depreciation, and the consequent balance sheets risk, the Central Bank of Brazil conducted an inquiry on corporate businesses to have a sense of the dimension of potential currency risks. As Table 6 indicates, dollar- 
denominated corporate risk debt seemed fairly small. In particular, the unhedged debt of firms that have no foreign counterpart amounted to only 3.3\% of GDP. This suggests that our assumption that only the government holds international debt is adequate from a purely quantitative viewpoint as well.

Table 6: Dollar Denominated Corporate Debt in June 2015

\begin{tabular}{lc}
\hline Type of Firm & Debt (\% GDP) \\
\hline Non exporter, with local hedge & 4.0 \\
Non exporter, multinational & 2.1 \\
Non exporter, with international assets & 3.6 \\
Non exporter, without hedge & 3.3 \\
\hline
\end{tabular}

Source: Central Bank of Brazil.

\section{Conclusion}

The past decade was characterized by two new trends in international capital flows to emerging markets: (1) carry trade activity and associated foreign participation in localcurrency bond markets, and (2) large accumulations of international reserves. We believe that both can be rationalized as an optimal debt management strategy. Borrowing in domestic currency can insure emerging countries against international shocks because the valuation effect that results from currency appreciation negatively correlates with the shock, an intuition that dates to Bohn (1990).

We revisit sovereign debt sustainability under the assumptions that countries can accumulate reserves and borrow internationally using their own currency. Countries do not accumulate reserves to be depleted in "bad" times. Instead, issuing domestic debt while accumulating reserves acts as a hedge against external shocks. Asset-valuation effects due to currency fluctuations act to absorb global shocks and smooth consumption. Our quantitative study of how reserve accumulation affects governments' decisions to default finds that 
optimal holdings turn out to be as large as those presently observed. Our results match several characteristics of the Brazilian business cycle, suggesting this strategy to be effective for smoothing consumption and reducing the occurrence of default.

\section{References}

Aguiar, Mark, and Manuel Amador (2014). "Sovereign Debt.” In Handbook of International Economics, vol. 4, eds. G. Gopinath, E. Helpman and K. Rogoff, Elsevier.

Aguiar, Mark, Satyajit Chatterjee, Harald Cole, and Zachary Stangebye. 2016. "Quantitative Models of Sovereign Debt Crises," Handbook of Macroeconomics, vol. 4, eds. Harald Uhlig and John Taylor.

Aizenman, Joshua, and Nancy Marion (2003). "International Reserve Holdings with Sovereign Risk and Costly Tax Collection,” The Economic Journal 114, 569-591.

Akinci, Orze (2011). "A Note on the Estimation of the Atemporal Elasticity of Substitution between Tradable and Nontradable Goods," Working Paper, Columbia University.

Alfaro, Laura, and Fabio Kanczuk (2005). "Sovereign Debt as a Contingent Claim: A Quantitative Approach,” Journal of International Economics 65, 297-314.

Alfaro, Laura, and Fabio Kanczuk (2009). “Optimal Reserve Management and Sovereign Debt," Journal of International Economics 77, 23-36.

Alfaro, Laura, and Fabio Kanczuk (2010). "Nominal versus Indexed Debt: A Quantitative Horse Race.” Journal of International Money and Finance 29, 1706-1726.

Arellano, Cristina (2008). "Default Risk and Income Fluctuations in Emerging Economies," American Economic Review 98(3): 690-712.

Backus, David K., Patrick J. Kehoe and Finn E. Kydland (1992). "International Real Business Cycles” The Journal of Political Economy, Vol. 100 (4), 745-775. 
Bank for International Settlements (2012). "Developments in Domestic Government Bond Markets in EMEs and their Implications," BIS Papers, no. 67.

Benetrix, Agustin S., Philip R. Lane, and Jay C. Shambaugh (2015). "International Currency Exposures, Valuation Effects and the Global Financial Crisis," Journal of International Economics forthcoming.

Benigno, Gianluca, and Luca Fornaro (2011). "Reserve Accumulation, Growth, and Financial Crises," CEP Discussion Paper No 1161.

Bianchi, Javier, Juan Carlos Hatchondo, and Leonardo Martinez (2012). "International Reserves and Rollover Risk,” Working Paper.

Bohn, Henning (1990). "Tax Smoothing with Financial Instruments," American Economic Review 80, 1217-1230.

Burger, John D., Francis E. Warnock, and Veronica Cacdac Warnock (2012). "Investing in Local-Currency Bond Markets," Financial Analysts Journal 68, 73-93.

Burstein, Ariel T., Joao C. Neves, and Sergio Rebelo (2003). "Distribution Costs and Real Exchange-Rate Dynamics during Exchange-rate-based Stabilizations," Journal of Monetary Economics 50, 1189-1214.

Central Bank of Brazil (2015) "Relatorio de Estabilidade Financeira", Setembro 2015: 27-30

Cole, Harald L., and Maurice Obstfeld (1991). "Commodity Trade and International Risk Sharing," Journal of Monetary Economics 28(1): 3-24.

Dooley, Michael, David. Folkerts-Landau, and Peter. Garber (2003). "An Essay on the Revived Bretton Woods System,” NBER Working Paper 9971.

Durdu, Ceyhun Bora, Enrique Mendoza, and Marco E. Terrones (2009). "Precautionary Demand for Foreign Assets in Sudden Stop Economies: An Assessment of the New Mercantilism," Journal of Development Economics 89, 194-209. 
Du, Wenxin, and Jesse Schreger (2016a). “Local Currency Sovereign Risk,” Journal of Finance 71(3), 1027-1070.

Du, Wenxin, and Jesse Schreger (2016b). "Sovereign Risk, Currency Risk, and Corporate Balance Sheets," Working Paper.

Eaton, J., Gersovitz, M., (1981). "Debt with potential repudiation: Theoretical and empirical analysis." Review of Economic Studies 48, 289-309.

Engel, Charles, 1999, “Accounting for U.S. Real Exchange Rate Changes,” Journal of Political Economy 107, pages 507-538.

Engel, Charles, and Akito Matsumoto (2009). “The International Diversification Puzzle when Goods Prices are Sticky: It's Really about Exchange-Rate Hedging, not Equity Portfolios," American Economic Journal: Macroeconomics 1, 155-188.

Eichengreen, Barry, and Ricardo Hausmann (1999). "Exchange Rates and Financial Fragility," In New Challenges for Monetary Policy, Proceedings of a symposium sponsored by the Federal Reserve Bank of Kansas City.

European Central Bank (2006). "The Accumulation of Foreign Reserves," Occasional Paper Series No. 43, February.

Garcia-Cicco, Javier \& Roberto Pancrazi \& Martin Uribe (2010). "Real Business Cycles in Emerging Countries?," American Economic Review 100(5), 2510-2531.

Gelos, R.G., Ratna Sahay, and Guido Sandleris (2011). "Sovereign Borrowing by Developing Countries. What Determines Market Access?" Journal of International Economics $83,243-254$.

Gourinchas, Pierre-Olivier and Helene Rey (2014), “External Adjustment, Global Imbalances and Valuation Effects," In Handbook of International Economics, vol. 4, eds. G. Gopinath, E. Helpman and K. Rogoff, Elsevier. 
Grossman, Hershel I. and Han, Taejoon (1999), "Sovereign Debt and Consumption Smoothing," Journal of Monetary Economics 44, 149-158.

Grossman, Hershel I. and Van Huyck, J. (1988), "Sovereign Debt as a Contingent Claim? Excusable Default, Repudiation, and Reputation" American Economic Review 78, 1088-97

Hale, Galina, Peter Jones, and Mark Spiegel (2014). “The Rise in Home Currency Issuance," San Francisco Fed Working Paper 2014-19.

Jeanne, Olivier, and Romain Rancière (2011). "The Optimal Level of Reserves for Emerging Market Countries: A New Formula and Some Applications," Economic Journal 121, 905-930.

Kanczuk, Fabio (2004). "Real Interest Rates and Brazilian Business Cycles," Review of Economic Dynamics 7, 436-455.

Levy Yeyati, E., Sturzenegger, F., (2003). "To float or to fix: Evidence on the impact of exchange rate regimes on growth,” American Economic Review 93 (4), 1173-1193.

Obstfeld, Maurice, Jay C. Shambaugh, and Alan M. Taylor (2010). "Financial Stability, the Trilemma, and International Reserves," American Economic Journal: Macroeconomics 2, 57-94.

Ottonello, Pablo and Diego Perez (2017) "The Currency Composition of Sovereign Debt," Working Paper.

Reinhart, Carmen (2010). "This Time Is Different Chartbook: Country Histories on Debt, Default, and Financial Crises,” NBER Working Paper 15815.

Rodrik, Dani (2006). “The Social Cost of Foreign Exchange Reserves,” NBER Working Paper 11952. 